\title{
A FUZZY ANALYTIC NETWORK PROCESS METHOD FOR RISK PRIORITIZATION IN FREEWAY PPP PROJECTS: AN IRANIAN CASE STUDY
}

\author{
Alireza VALIPOUR ${ }^{\mathrm{a}}$, Nordin YAHAYA ${ }^{\mathrm{a}}$, Norhazilan MD NOOR ${ }^{\mathrm{a}}$, Simona KILDIENE $^{\mathrm{b}}$, \\ Hadi SARVARI ${ }^{\mathrm{a}}$, Abbas MARDANI ${ }^{\mathrm{c}}$ \\ ${ }^{a}$ Department of Structure and Materials, Faculty of Civil Engineering, Universiti Teknologi Malaysia, \\ Skudai, 81310, Johor, Malaysia \\ ${ }^{b}$ Department of Construction Technology and Management, Vilnius Gediminas Technical University, \\ Sauletekio al. 11, LT-10223 Vilnius, Lithuania \\ ${ }^{c}$ Faculty of Management, Universiti Teknologi Malaysia, Skudai, 81310, Johor, Malaysia
}

Received 12 Feb 2015; accepted 21 Apr 2015

\begin{abstract}
Risk assessment is one of the most important factors in achieving success in public-private partnership (PPP) projects. Some relationships between risks in freeway projects have been established. The occurrence of each risk can worsen the effects of others such as a negative impact of financial risks on construction risks. This paper is aimed at prioritizing significant risks in freeway PPP projects applying a fuzzy analytic network process (FANP) method for overcoming the problems of interdependencies and feedback among different risk-ranking alternatives. Data on the study have been collected through a literature review, an interview and a questionnaire survey distributed to experts in the field of freeway PPP projects. The obtained results have shown that financial, legal and political risks are the most significant groups, although improper design, changes in the value of granted lands and the termination of concession are the most important risks. The findings help with strengthening the capabilities of developing countries for risk management in freeway PPP projects.
\end{abstract}

Keywords: risk prioritzation, PPP projects, fuzzy method, ANP method, freeway projects.

\section{Introduction}

In recent years, an increased interest in developing countries regarding cooperation among public and private sectors to develop and operate infrastructure projects such as transportation, water, electrical power, telecommunications and sports facilities in particular has been observed (Heravi, Hajihosseini 2011; Li, Zou 2011; Tserng et al. 2014; Xu et al. 2014). Public-private partnership (PPP) projects are normally implemented to secure public projects through private investment (Xu et al. 2010); yet, serious shortages of experience, a paucity of relevant studies and complex PPP agreements in developing countries can be noticed (Heravi, Hajihosseini 2011). Construction delays and cost overrun are important issues of infrastructure projects (Rajan et al. 2013). Some global PPP projects such as the Betuwe Railway in Netherlands ( $\mathrm{Ng}$, Loosemore 2007), a project of the railway in Sydney (Zhang 2005), Malaysian Privatized National Sewerage project, Parkeerschap Den Bosch, the Sydney AirportLink, the Sydney Cross City Tunnel, the 9th Water Plant in Shen Yang, the 4th Min Jiang River Bridge in Fuzhou City and the Hou Shi power plant in Zhang
Zhou City have been reported to be unsuccessful (Li, Zou 2011). The failures of the project are mostly due to insufficient project management as well as because of the innate features of construction projects (Ribeiro et al. 2013). There are many potential risks in the process of PPP projects due to large investment, a long contractual concession period and complex technology (Heravi, Hajihosseini 2011). In this regard, international contractors are experiencing more serious political risks (Deng et al. 2014). Potential risks often lead to large losses on project stockholders (Li, Zou 2011). Delmon (2000) stated that the impact of risks in completing a PPP project was significant because those risks could be described as uncertain events that had a negative effect on the objectives of the project and involved cost, time, quality and scope.

Since the PPP scheme has been adopted worldwide, numerous studies have been conducted to identify factors having a critical influence on the success of PPP projects (Xu et al. 2012; Chou et al. 2013; Berner et al. 2014; Yun et al. 2015). Berner et al. (2014) presented an article discussing the primary results of "Risk Assessment of PPP contracts". The fundamentals of risk management

Corresponding author: Simona Kildiene

E-mail: simona.kildiene@vgtu.lt 
as well as a developed risk-checklist are discussed in detail. This checklist enables to identify and assess projectrelated risks quickly and efficiently as well as to ultimately control the introduced risks in a precise manner. Ke et al. (2012) examine risk management practice in PPP projects in China. The other objectives of this study include the identification of the factors limiting the application of risk management theories, and the introduction of measures for improving the practice of the project on risk management. The absence of a risk management culture was found to be the dominant factor that limited the implementation of risk management in practice. $\mathrm{Xu}$ et al. (2012) present the third stage of a funded study aimed at developing a practical and computerized risk evaluation model for PPP projects. At the first and second stages, a risk hierarchal structure composed of 17 weighted risk factors has been developed to describe risk profiles of PPP projects that usually involve more risks than other traditional procurement models because of their complexity. The shortage of comprehensive risk assessment is one of the dominant factors that contribute to the failure of PPP projects (Li, Zou 2011). Reducing the probability of project failure is one of the targets of the project on risk management (Teller et al. 2014). Risk assessment is a vital component of the risk management process. According to the previous studies, a reliable risk assessment model is essential to ensure the success of PPP projects (Xu et al. 2010). The aim of this study is to propose the fuzzy analytical network process (FANP) as a risk prioritization method for simulating the ambiguity of human judgment and developing a risk prioritization accuracy technique associated with PPP freeway projects in IRAN. It is believed that this research study can shed light on managing freeway PPP risks in IRAN and developing countries. The findings of this study can be applied through the Government to enhance the risk prioritization process that may encourage the participation of private sectors through better risk assessment. The results of the carried out research can help project owners, contractors and subcontractors in better risk management, cost and time savings and improvement in the overall quality of freeway PPP projects, particularly in developing countries.

\section{Literature review}

In recent years, risk studies on the PPP project have gained attention among researchers and industry decision-makers. For example, fuzzy-AHP-based risk assessment and a fuzzy synthetic evaluation approach to PPP projects were established to assess risk factors in the PPP expressway project in China (Li, Zou 2011; Xu et al. 2010). Mousavi et al. (2011) also developed a risk assessment model for highway projects using the jackknife technique. In addition, the use of the ANP to evaluate risk has been practiced by Tang et al. (2011) on urban rail transit projects in China and by Valipour et al. (2013) on a gas refinery EPC in Iran. Yu and Lee (2012) also proposed a conflict-risk assessment model for an urban regeneration project based on the fuzzy-failure mode and effect analysis (Fuzzy-FMEA). The above mentioned literature clearly attests the importance of risk assessment in the execution of PPP projects.

Risks in construction PPP projects are various and complex, because each risk is mutually independent and bear a reciprocal influence on other risks (APM 2004; Bu-Qammaz et al. 2009; Nasirzadeh et al. 2008; Shrestha 2011). Certain risks are inherent in all construction projects and are faced by all parties involved in the project - owners, contractors, designers, suppliers, etc. (Peckiene et al. 2013). Construction projects can be extremely complex and fraught with uncertainty. Risk and uncertainty can potentially have damaging consequences for construction projects. For example, changes in legislation can result in the alteration of regulatory laws, protectionism policy and influence on political decision making that may also lead to changes in legislation. In this regard, the Port of Miami Tunnel (POMT) project is a good example that remained at the planning stages for two decades due to insufficient support at the state level (Shrestha 2011). Another example is the Act of God risk that is a risk of uncertain activities having adverse impacts on construction. This could also cause damage to equipment, affect labor during construction and initiate delays and cost overrun.

All above introduced along with a number of other examples indicate that lack of evaluating relationships and feedback among risks on project objectives is one of the reasons behind the weak accuracy of risk assessment and risk analysis of construction projects and PPP projects (Nasirzadeh et al. 2008; Tang et al. 2011; Peckiene et al. 2013; Turskis et al. 2012). To support this, Zegordi et al. (2012) developed a FANP-TOPSIS method for the risk assessment of EPC power plant project risks in Iran focusing on dependency and feedback among different criteria for risk assessment such as probability and impact. However, the final ranking of risk in this study does not consider the relationships among risks or feedback. In addition, the proposed model can simultaneously assess more than 10 risks. Poh and Tah (2006) used influence networks to capture interdependencies among the factors affecting the duration and cost of construction activity. Nasirzadeh et al. (2008) also investigated the System Dynamic (SD) method for risk analysis with a focus on addressing interdependencies and feedback among risk factors. The SD risk assessment method can be complex and have limitations because of the complexity of simulation modeling. The quantification of mathematical equations has been formulated to represent the dependencies of each risk, and therefore has been required for a long time. If a project is carried out in a new setting and environment, managers might fall short of such data. However, the SD method can evaluate risks but ranking them cannot be performed applying this method. Also, many 
problems are ill-defined and imprecise, and the fact is that these methods fail to address. Such techniques have not considered interdependencies and feedback among risks in order to achieve a group of prioritized risks.

It is to be noted that the analytic network process (ANP) can handle the problems of interdependencies and feedback among various risk rankings and is a reliable technique for measuring the level of risk (Bu-Qammaz et al. 2009). Regardless of the advantages of the ANP method, Razmi et al. (2009) implied the pairwise comparison stage as an ANP disadvantage. Due to the uncertainty and vagueness of the judgments made by decision makers, a crisp pairwise comparison in the traditional ANP appears to be insufficient and too imprecise to catch proper judgments associated with decision makers. Additionally, subjectivities and substantial uncertainties in risk assessment practice have affected the applicability of several risk assessment methods (Baloi, Price 2003).

Notably, the use of a fuzzy set concept in risk assessment permits qualitative risk assessment explanations to be modelled mathematically. Linguistic terms for instance, high probability, a minor impact or low risk cannot be defined meaningfully with an exact single value. The fuzzy set theory supplies a means through which these terms could be formally defined in mathematical logic (Carr, Tah 2001). It permits assessors to quantify incorporate vagueness and imprecise information in the assessment. Attempts have been made to exploit fuzzy logic in the risk assessment domain.

Thus, this study introduces a fuzzy logic in the pairwise comparison of the ANP to make up this deficiency in the conventional ANP, called the fuzzy ANP. This study proposes the fuzzy analytical network process (FANP) as a risk prioritization technique with a focus on providing feedback and interdependencies among risks and on simulating the ambiguity of human judgment thus bridging these gaps in risk-ranking methods for freeway PPP projects.

\section{Research method}

To identify risk factors in PPP projects, data on this study were primarily obtained through a comprehensive literature review. The questionnaire survey and interviews were conducted as secondary resources to achieve the objectives such as to identify and prioritize important risks found in Iranian PPP projects. An expert Delphi team was then organized to support the questionnaire survey. In the first round of the survey, the respondents were first requested to assign the estimated probability of occurrence based on a nine-point scale (Chang scale). Second, they had to estimate the impact of the described risk on a scale from 1 to 9 and add any new additional risk factors that were not included in Round 1 of the survey. As for Round 2, the respondents were provided with consolidated results from Round 1 and were invited to reconsider their scores to see if they would like to adjust their original choice.

For this study, 50 experts from Iran, including project managers, estimating managers, main contractors, quantity surveying managers, subcontractors and technical directors were selected. The experts participated in Tehran-Qom Highway, Tehran-Saveh Freeway, Sevad Kooh RD, Tehran-Isfahan Highway, Isfahan-Shiraz freeway and Turkmenistan-Mashhad-Mazandaran Project. They all had over five years of experience in PPP projects and were mostly at top managerial levels. The respondents had to meet two criteria before being invited to participate in the survey; first, to have extensive work experience within the construction industry of Iran, and second, to be involved in the management of PPP projects or have gained an in-depth knowledge of the PPP model through research. Table 1 shows the background information of the respondents: $58.2 \%$ of those came from the private sector, $32.6 \%$ - from the public sector and the rest - mainly comprised of the selected researchers and academics. Furthermore, nearly $63 \%$ of the respondents had industrial experience between 5-10 years.

Table 1. Background information on the selected experts

\begin{tabular}{|c|c|c|c|c|c|c|}
\hline \multicolumn{7}{|c|}{ Role of the respondents } \\
\hline Sector & Public & \multicolumn{3}{|c|}{ Private } & \multicolumn{2}{|c|}{ Academic } \\
\hline Percentage & 32.6 & \multicolumn{3}{|c|}{58.2} & \multicolumn{2}{|c|}{9.2} \\
\hline \multicolumn{7}{|c|}{ Position } \\
\hline Category & $\begin{array}{l}\text { Project } \\
\text { manager }\end{array}$ & $\begin{array}{l}\text { Estimating } \\
\text { manager }\end{array}$ & $\begin{array}{l}\text { Main } \\
\text { contractor }\end{array}$ & $\begin{array}{c}\text { Quantitysurveying } \\
\text { manager }\end{array}$ & $\begin{array}{c}\text { Sub } \\
\text { contractor }\end{array}$ & $\begin{array}{l}\text { Technical } \\
\text { director }\end{array}$ \\
\hline Number & 10 & 8 & 11 & 7 & 6 & 8 \\
\hline \multicolumn{7}{|c|}{ Type of PPP projects the surveyed respondents have been involved } \\
\hline Category & \multicolumn{2}{|c|}{ Transport } & \multicolumn{2}{|c|}{ Water Treatment } & \multicolumn{2}{|c|}{ Electrical Power } \\
\hline Number & \multicolumn{2}{|c|}{36} & \multicolumn{2}{|r|}{6} & \multicolumn{2}{|c|}{8} \\
\hline \multicolumn{7}{|c|}{ Industrial experience of the respondents } \\
\hline Years & \multicolumn{2}{|c|}{ Five or below } & $5-10$ & \multicolumn{2}{|l|}{$11-15$} & Above 16 \\
\hline Percentage & \multicolumn{2}{|c|}{0} & 62.5 & \multicolumn{2}{|l|}{20.4} & 17.1 \\
\hline
\end{tabular}




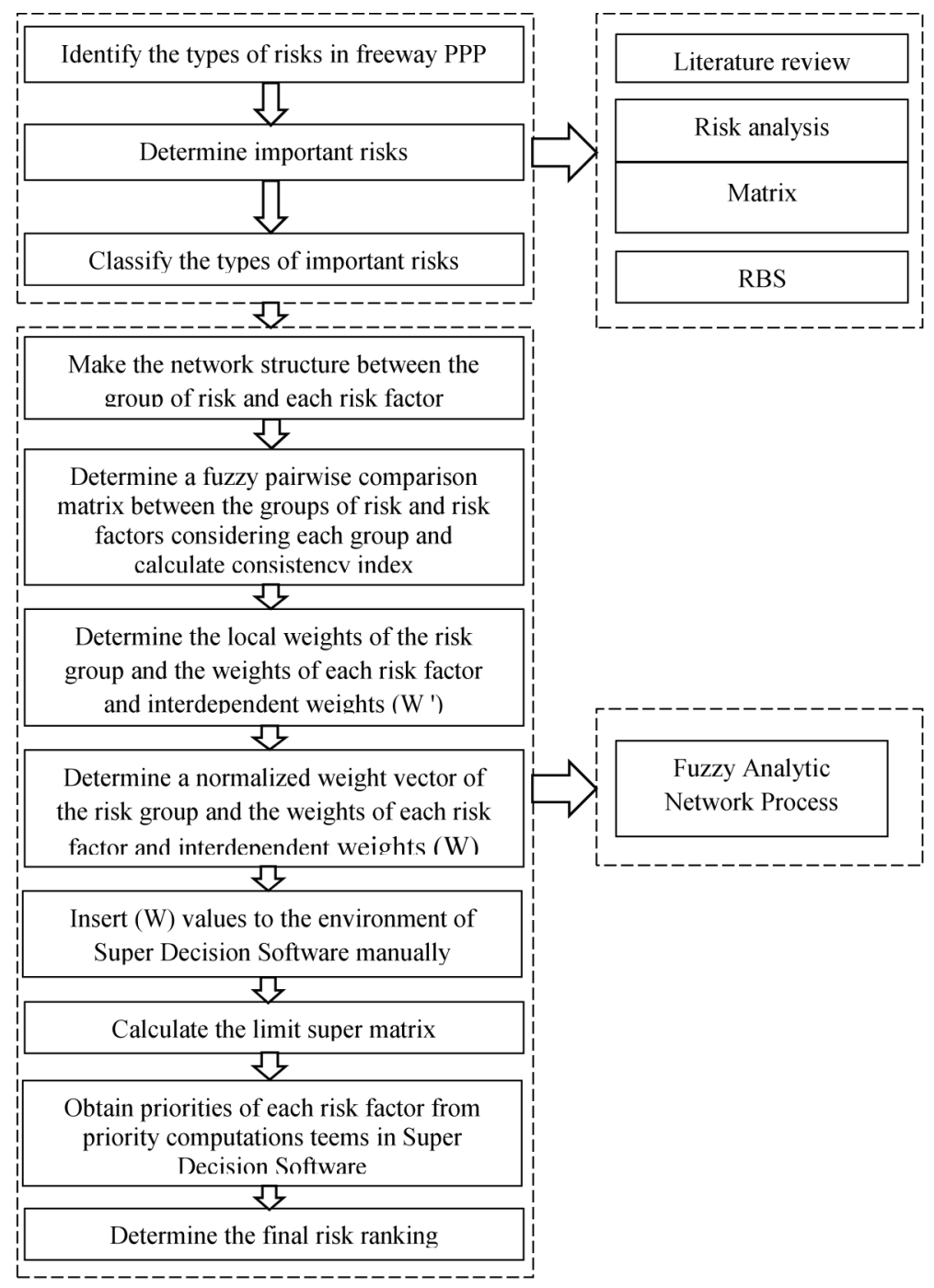

Fig. 1. Schematic illustration of research methodology

The flow of the research methodology for this study is schematically shown in Figure 1. The following sections describe the methods applied at each stage.

\subsection{Mean index}

According to qualitative methods and research questionnaire, the participants were required to individually reveal the level of the frequency of the risk event and the degree of risk impact. In this regard, mean analysis was used for determining the mean of frequency and risk impact. Mean can be calculated using SPSS according to the formula below (Alireza et al. 2013):

$$
\text { Mean Index }=\frac{\sum a_{i} x_{i}}{N},
$$

where: $a_{i}$ - the constant expressing the weight to each response (1 to 5).

Discrepancies in the expression for calculating the severity index, where $X_{0}$ should be $X_{1}=$ frequency of a "not effective" response and correspond to $a_{1}=1$, not $a_{2}=0 ; X_{2}=$ the frequency of a "moderately effective" response in which the term "moderately" was excluded; $x_{i}=$ the frequency of the response; $N=$ the total number of responses.

The mean results of frequency and risk impact were then used for calculating the risk score.

\subsection{Risk analysis matrix}

A risk analysis matrix is really a quantitative method that uses a subjective evaluation table of low, medium and high indications to demonstrate the amount of every type of the above mentioned risk. Risk scores are determined by multiplying the mean of frequency and the mean of risk impact shown as follows (Alireza et al. 2013):

$$
\text { Risk Score }=F_{r} \times I_{r} \text {. }
$$

In this formula, $F_{r}$ is the mean of the frequency of risk occurrence and $I_{r}$ is the mean of risk impact. The respondents are presented with referenece to a scale to 
rate the provided statements based on how frequently risk occurs and considering its impact using the 5-point Likert Scale that includes a continuum (minimum to maximum) in the direction of a particular statement that helps with recognizing the outcome. This rating system is applied to the frequency levels of PPP project risk occurrence and the impact level of PPP risk (see Tables from 2 to 4). Consequently, a list of the major risks in Iranian freeway PPPs is the core objective of this step.

Table 2. Five-point Likert scale for the frequency level of PPP

\begin{tabular}{c|l}
\hline Scale & \multicolumn{1}{|c}{ Indication } \\
\hline 1 & Very low frequency \\
2 & Low frequency \\
3 & Moderate Frequency \\
4 & High Frequency \\
5 & Very High Frequency \\
\hline
\end{tabular}

Table 3. Five-point Likert scale for the impact level of PPP Risk

\begin{tabular}{c|l}
\hline Scale & \multicolumn{1}{|c}{ Indication } \\
\hline 1 & Insignificant \\
2 & Minor \\
3 & Moderate \\
4 & Major \\
5 & Sever \\
\hline
\end{tabular}

Table 4. Risk analysis matrix

\begin{tabular}{l|c|c|c|c|c|c}
\hline \multicolumn{1}{c|}{ Frequency } & \multicolumn{5}{c}{ Risk Impact } \\
\hline \multicolumn{2}{c|}{} & \multicolumn{1}{c}{$\begin{array}{c}\text { Insigni- } \\
\text { ficant }\end{array}$} & Minor & Moderate & Major & Severe \\
\cline { 3 - 7 } 1 & 2 & 3 & 4 & 5 & \\
\hline Very High & 5 & 5 & 10 & 15 & 20 & 25 \\
High & 4 & 4 & 8 & 12 & 16 & 20 \\
Moderate & 3 & 3 & 6 & 9 & 12 & 15 \\
Low & 2 & 2 & 4 & 6 & 8 & 10 \\
Very low & 1 & 1 & 2 & 3 & 4 & 5 \\
\hline
\end{tabular}

Score: 1-4: Low; 5-14: Medium; 15-25: High

\subsection{Analytic network process}

The analytic network process (ANP) is a generic form of an analytic hierarchy process (AHP) developed by Saaty and Vargas (2006) to solve complex decision-making problems. The ANP has been acknowledged as a powerful method for determining complex interrelationships and incorporating feedback among decision levels and attributes. This method is mainly used for defining the relationship between the clusters of the elements that influence each other and are influenced by the elements in other clusters. In fact, the ANP enables researchers to analyze influences separately depending on many factors and then combines them in a single result (Ayağ, Özdemir 2007; Chan et al. 2008). Shafieezadeh and
Hajfataliha (2009) declared that the ANP was the most accurate method for modelling complex decision-making problems. According to Rabbani et al. (2014), the ANPbased decision analysis approach can measure all tangible and intangible criteria for the model; the ANP is a relatively simple, intuitive approach that can be accepted by managers and other decision-makers; the ANP allows for more complex relationship among decision levels and attributes as it does not require a strict hierarchical structure, and the ANP is more adapted with real world problems.

The ANP comprises two parts (Azizi, Modarres 2007). The first one contains a control hierarchy or a network relative to the goal, criteria and subcriteria that govern interactions in the process. The second embraces an influence network among the elements and the clusters. The decision network includes the clusters, elements and links. There are relevant elements within a network or subnetwork in a cluster. The clusters with their elements are determined considering each control criterion. Inner and outer dependencies in the ANP can be observed. Interactions and feedback within the clusters are called inner dependencies while interactions and feedback between the clusters are called outer dependencies (Saaty 1996).

In the ANP, pairwise comparison judgments can be used for determining relevant importance and dominance among the elements and components. The ANP uses Saaty's nine-point scale (1-9) to match the AHP (Wu et al. 2008). Each number in the comparison matrix is used for exposing an subjective opinion and the experience of a participatant (Bayazit 2006). The respondent can verbally indicate his/her preference between each pair of the elements. The supermatrix is developed to handle dependencies among the clusters and elements by computing composite weights. However, a decision-maker may misinterpret opinions and may be uncertain in dedicating the evaluation to a different number. Uncertainty may exist as a result of incomplete information, inaccurate information, and partial ignorance (Cheng, Tang 2009; Wu et al. 2008). Hence, AHP and ANP methods might fail to adequately handle associated ambiguities and inherent uncertainty with mapping the decision-maker's concept to the exact numbers (Vahidnia et al. 2008).

\subsection{Fuzzy ANP}

Zadeh (1976) introduced the fuzzy set theory to deal with problems regarding the explanation of activities and perceptions, and judgments are intellectually ambiguous (Kaur, Mahanti 2008; Zadeh 1976). The fuzzy set theory can be classified into five branches: fuzzy set mathematics, fuzzy logic and artificial intelligence, fuzzy systems, uncertainty and information and fuzzy decision making. The main contribution of the fuzzy set theory is its ability to display vague data. Despite fuzzy logic having many complex operations, it has many practical applications. Triangular and trapezoidal fuzzy numbers are often used 
in applications because of their calculation simplicity and usefulness in information processing and promoting presentation in a fuzzy environment (Ertuğrul, Karakaşoğlu 2009). A triangular fuzzy number is described by three real numbers: $l, m$ and $u$. These parameters denote the smallest possible value, the most promising value and the largest possible value respectively. For example, in a pairwise comparison, a decision maker supplies a crisp number $X$; thus, we can "fuzzify" the crisp number of triangular fuzzy numbers. The fuzzy set theory has been successfully compounded in the ANP by using a fuzzy ratio in the pairwise comparison rather than a crisp ratio as in Saaty's nine-point scale.

According to the ANP method, the fuzzy ANP (FANP) has a number of advantages. The FANP method uses a linguistic scale that helps an expert or decision maker in preparing a more flexible method for reaching a conclusion. Because the FANP is a comprehensive, multipurpose decision method, the previous research has used the FANP for solving many complex decision-making problems. FANP utilization in risk assessment and decision support systems of diverse areas can be referred to in Mikhailov and Singh Madan (2003), Dağdeviren and Yüksel (2010), Eshtehardian et al. (2013) and Shafiee (2015).

\subsection{FANP model based on Chang's method}

The FANP has been widely employed for calculating priority weights from fuzzy comparison matrices, because it is relatively simpler than other FAHP methods. For instance, Guneri et al. (2009) used the FANP approach for selecting a shipyard location by incorporating the extent analysis method as introduced by Chang (1996). Let $X=\left\{x_{1}, x_{2}, \ldots, x_{n}\right\}$ be an object set and $U=\left\{u_{1}, u_{2}, \ldots\right.$, $\left.u_{n}\right\}$ be a goal set. According to the method of Chang's extent analysis, each object is taken and an extent analysis of each goal $\left(g_{i}\right)$ is performed. Thus, $m$, the extent analysis values of each object, can be obtained with the following signs:

$$
M_{g_{i}}^{1}, M_{g_{i}}^{2}, \ldots, M_{g_{i}}^{m}, \quad i=1,2, \ldots n,
$$

where $M_{g_{i}}^{j}(j=1,2, \ldots, m)$ whereby all are triangular fuzzy numbers. Here, the steps of the Chang's extent analysis method are provided.

Step 1. The value of fuzzy synthetic extent, with respect to the $i^{\text {th }}$ object, is defined as:

$$
S_{i}=\sum_{j=1}^{m} M_{g_{i}}^{j} \otimes\left[\sum_{i=1}^{n} \sum_{j=1}^{m} M_{g_{i}}^{j}\right]^{-1}
$$

To obtain $\sum_{j=1}^{m} M_{g_{i}}^{j}$ the fuzzy addition operation of $m$ extent analysis values of a particular matrix is performed as:

$$
\sum_{j=1}^{m} M_{g_{i}}^{j}=\left(\sum_{j=1}^{m} l_{j}, \sum_{j=1}^{m} m_{j}, \sum_{j=1}^{m} u_{j}\right)
$$

To obtain $\left[\sum_{i=1}^{n} \sum_{j=1}^{m} M_{g_{i}}^{j}\right]^{-1}$, the fuzzy additional operation of $M_{g_{i}}^{j}(j=1,2, \ldots, m)$ values are performed as:

$$
\sum_{i=1}^{n} \sum_{j=1}^{m} M_{g_{i}}^{j}=\left(\sum_{i=1}^{n} l_{i}, \sum_{i=1}^{n} m_{i}, \sum_{i=1}^{n} u_{i}\right) .
$$

Then, compute the inverse of the vector in Eqn (4) such that:

$$
\left[\sum_{i=1}^{n} \sum_{j=1}^{m} M_{g_{i}}^{j}\right]^{-1}=\left(\frac{1}{\sum_{i=1}^{n} u_{i}}, \frac{1}{\sum_{i=1}^{n} m_{i}}, \frac{1}{\sum_{i=1}^{n} l_{i}}\right)
$$

Step 2. The degree of possibility of $M_{2}=\left(l_{2}, m_{2}, u_{2}\right)$ $\geq M_{1}=\left(l_{1}, m_{1}, u_{1}\right)$ is defined as:

$$
V\left(M_{2} \geq M_{1}\right)=\sup _{y \geq x}\left[\min \left(\mu_{M_{1}}(x), \mu_{M_{2}}(y)\right)\right]
$$

and can be equivalently expressed as follows:

$$
\begin{aligned}
& V\left(M_{2} \geq M_{1}\right)=\operatorname{hgt}\left(M_{1} \cap M_{2}\right)=\mu_{M_{2}}(d)= \\
& \begin{cases}1 & \text { if } \mathrm{m}_{2} \geq m_{1} \\
0 & \text { if } \mathrm{l}_{1} \geq u_{2} \\
\frac{l_{1}-u_{2}}{\left(m_{2}-u_{2}\right)-\left(m_{1}-l_{1}\right)} & \text { otherwise }\end{cases}
\end{aligned}
$$

where $d$ is the ordinate of the highest intersection point $D$ between $\mu_{m_{1}}$ and $\mu_{m_{2}}$. To compare $M_{1}$ and $M_{2}$, we need both the values of $V\left(M_{1} \geq M_{2}\right)$ and $V\left(M_{2} \geq M_{1}\right)$.

Step 3. The degree of the possibility of a convex fuzzy number to be greater than $k$ convex fuzzy numbers, $M_{i}(i=1,2, \ldots, k)$ can be defined by:

$$
\begin{gathered}
V\left(M \geq M_{1}, M_{2}, \ldots, M_{K}\right)=V\left[\left(M \geq M_{1}\right) \text { and }\left(M \geq M_{2}\right)\right. \\
\quad \text { and }, \ldots \\
\left(M \geq M_{K}\right)=\min V\left(M \geq M_{i}\right), \quad i=1,2, \ldots, k . \quad(10)
\end{gathered}
$$

Assume that $d^{\prime}\left(A_{i}\right)=\min V\left(S_{i} \geq S_{K}\right)$. For $k=1,2, \ldots, n$; $k \neq I$. Then, the weight vector is given by:

$$
W^{\prime}=\left(d^{\prime}\left(A_{1}\right), d^{\prime}\left(A_{2}\right), \ldots, d^{\prime}\left(A_{n}\right)\right)^{T},
$$

where: $A_{i}$ are $n$ elements.

Step 4. The normalized weight vectors are:

$$
d\left(A_{i}\right)=\frac{d^{\prime}\left(A_{i}\right)}{\sum_{i=1}^{n} d^{\prime}\left(A_{i}\right)}
$$




$$
W=\left(d\left(A_{1}\right), d\left(A_{2}\right), \ldots, d\left(A_{n}\right)\right)^{T},
$$

where $W$ is a non-fuzzy number.

\section{Case study on risk prioritization in the Iranian freeway PPP project}

\subsection{Case study debriefing}

The development of a road network is extremely important in Iran as a developing country with diverse geographical conditions. The Iranian government is interested in seeking private investment to build and maintain road networks via a PPP agreement. According to the proposed model, the process of risk prioritization of Isfahan-Shiraz freeway project in Iran is studied in this section. The project was launched in 2010 by a private-sector entity through the PPP agreement. Isfahan-Shiraz freeway is currently being built in order to shorten the distance between these two historic and tourist towns (Isfahan-Shiraz) to the extent of $140 \mathrm{~km}$, reduce the travel time to 1.5 hours, decrease fuel consumption by 136 million liters per year and reduce accidents on the road. The Iranian civilization, road construction company and Mollalmovahedin financial institution were designated as the private sector entity via a BOT agreement and provides $50 \%$ of the total capitalization of the project by these companies. The project includes a total length of $210 \mathrm{~km}, 2$ lanes, 700 small bridges and 15 large bridges and 6200 meters of tunnels. At present, the cost of the project is estimated at more than US\$ 2 billion.

The following step is a comparison of risk prioritization between finding this study in compliance with the actual findings from the previous researches (Ghorbani et al. 2014; Mousavi et al. 2011; Heravi, Hajihosseini 2011). In terms of the common prioritization of top 10 risks between this study and Ghorbani et al. (2014), there are 7 that received the same prioritization between these 2 studies: 'inflation risk $\left(r_{12}\right)$ ', 'limited capital $\left(r_{16}\right)$ ', 'improper design $\left(r_{21}\right)$ ', 'inadequate study and insufficient data $\left(r_{23}\right)$ ', 'change in the value of granted lands due to development $\left(r_{11}\right)$ ', 'termination of concession by the Government $\left(r_{31}\right)$ ' and 'financial problems due to environmental protection $\left(r_{14}\right)^{\prime}$. Also, there are 5 and 8 common prioritizations of top 10 risks between this study, according to Mousavi et al. (2011) and Heravi and Hajihosseini (2011), respectively. These common risks included 'severe weather $\left(r_{71}\right)$ ', 'delay in resolving contractual dispute $\left(r_{22}\right)$ ', 'improper design $\left(r_{21}\right)$ ', 'inadequate study and insufficient data $\left(r_{23}\right)$ ', 'financial problems due to environmental protection $\left(r_{14}\right)$ ', 'limited capital $\left(r_{16}\right)$ ', 'inflation risk $\left(r_{12}\right)$ ' and 'change in the value of granted lands due to inflation $\left(r_{13}\right)$ '.

\subsection{Risk identification and classification of important risks}

Risk identification is the first step in risk management procedures. In order to identify risk factors in the select-

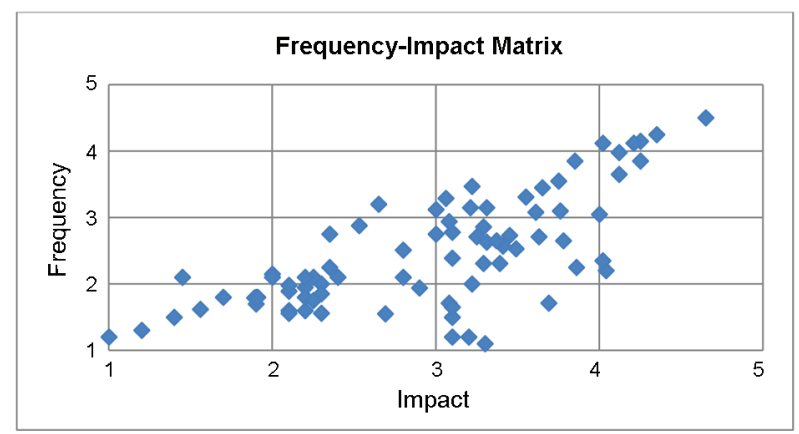

Fig. 2. Frequency-impact matrix

ed study, a decision-making group comprising a project manager, designer, project stakeholder and PPP project contractor was established. The primary result of this step was to genarete a list of possible important risks. Data were collected through the previous studies on PPP highway projects (Ebrahimnejad et al. 2010; Heravi, Hajihosseini 2011; Karim, Alkaf 2011; Li, Zou 2011; Mousavi et al. 2011; Xu et al. 2010; Alireza et al. 2013). As a result, 81 risks were identified.

Data collection was also based on a comprehensive set of a questionnaire and interview sessions involving different PPP experts as shown in Table 1 and a document review. Data were collected through questionnaires distributed using email and in person amongst a sample of public and private sectors in Iranian freeway PPP projects. A total of 150 questionnaire forms were distributed to the respondents. In the end, 82 valid questionnaires, including 42 from the private sector and 40 from the public sector, were obtained for this study. Based on the survey outcomes, a mean score was computed for each project based on the related risk frequency and risk impact. These risks were then ranked according to risk score and the risk analysis matrix (scales 1-25). As a result, 27 important risks were identified in the project. Figure 2 shows the frequency-impact matrix and Table $5-27$ significant risks in freeway PPP projects.

Risk breakdown structure (RBS) was then applied to classify risks based on the risk resource and an impact on the project. While applying RBS, 27 risks were classified according to the source of their creators (project managers, designers, key project stakeholders and a contractor) to determine when the impact might occur in the life cycle of the project. A total of 27 important risks with a high probability of occurrence were identified, which had a critical impact on the objectives of the project, including time, cost and quality. The received 27 risks were then grouped into seven categories by expert judgments with the help of the Delphi method for the project, as shown in Table 5.

\subsection{Creating a risk network structure}

After the identification and categorization of important risks, a network structure was constructed to create mutual influence among risk factors based on risk assess- 
Table 5. Important risks in the Iranian freeway PPP project (Isfahan-Shiraz)

\begin{tabular}{|c|c|}
\hline Risk groups & Types of risks \\
\hline \multirow[t]{6}{*}{$R_{1}:$ Financial } & $\begin{array}{l}r_{11}: \text { Change in the value of granted lands } \\
\text { due to development }\end{array}$ \\
\hline & $r_{12}:$ Inflation risk \\
\hline & $\begin{array}{l}r_{13}: \text { Change in the value of granted lands } \\
\text { due to inflation }\end{array}$ \\
\hline & $\begin{array}{c}r_{14}: \text { Financial problems due to } \\
\text { environmental protection }\end{array}$ \\
\hline & $r_{15}:$ Need for land appraisal \\
\hline & $r_{16}:$ Limited capital \\
\hline \multirow[t]{7}{*}{$R_{2}:$ Legal } & $r_{21}:$ Improper design \\
\hline & $\begin{array}{l}r_{22}: \text { Delay in resolving a contractual } \\
\text { dispute }\end{array}$ \\
\hline & $\begin{array}{l}r_{23}: \text { Inadequate study and insufficient } \\
\text { data }\end{array}$ \\
\hline & $r_{24}:$ Need for environmental approval \\
\hline & $r_{25}:$ Ownership assets \\
\hline & $\begin{array}{l}r_{26}: \text { Lack of a standard model for PPP } \\
\text { agreements }\end{array}$ \\
\hline & $r_{27}:$ Need for land acquisitions \\
\hline \multirow[t]{4}{*}{$R_{3}:$ Political } & $\begin{array}{l}r_{31}: \text { Termination of concession by the } \\
\text { Government }\end{array}$ \\
\hline & $r_{32}:$ Change in law \\
\hline & $r_{33}:$ Influential economic events \\
\hline & $r_{34}:$ Sanction \\
\hline \multirow[t]{4}{*}{$R_{4}$ : Market } & $r_{41}$ : Change in market demand \\
\hline & $r_{42}:$ Tariff change \\
\hline & $r_{43}:$ Insufficient income \\
\hline & $r_{44}:$ Competition \\
\hline \multirow[t]{3}{*}{$R_{5}:$ Operation } & $r_{51}:$ Operator default \\
\hline & $r_{52}:$ Operation cost-overruns \\
\hline & $r_{53}:$ High maintenance costs \\
\hline \multirow{2}{*}{$\begin{array}{l}R_{6}: \text { Organization } \\
\text { and coordination }\end{array}$} & $r_{61}:$ Coordination risk \\
\hline & $r_{62}:$ Organization risk \\
\hline $\begin{array}{l}R_{7}: \text { Force } \\
\text { majeure }\end{array}$ & $r_{71}$ : Severe weather, war, natural disasters \\
\hline
\end{tabular}

ment by five freeway project experts that were selected considering longer than 10 years experience (Section 2, Table 1). For assessing risk in this structure, outer dependency among different groups and inner dependency within each group of risks were noticed. A comparison of the indirect dominance of factors in factor set $R_{i}$ was carried out according to their influence on $r_{i j}$ considering factor set $R_{i}(i=1,2, \ldots, 7)$ as the primary standard and factor set $r_{j}(j=1,2, \ldots, 7)$ as a secondary standard to construct a judgment matrix. The ANP network process of risk factors is shown in Figure 3.

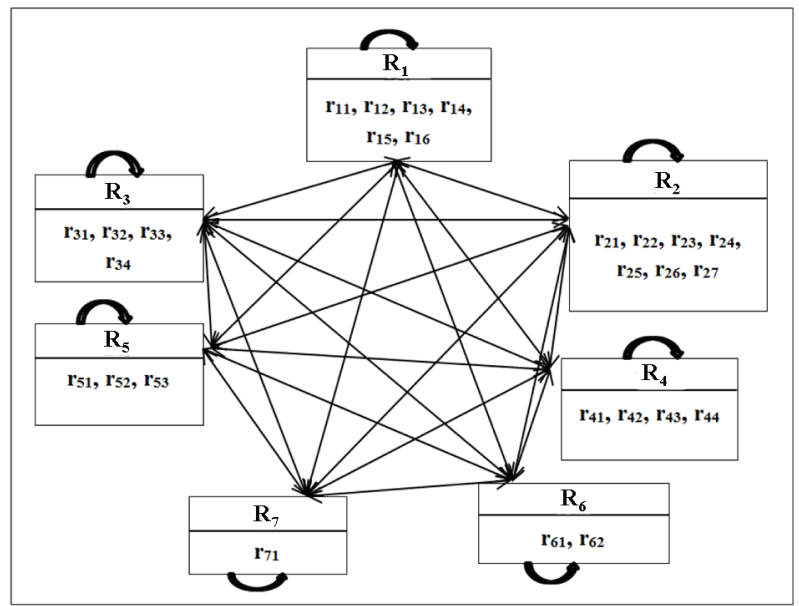

Fig. 3. The ANP network process of risk factors

\subsection{Pairwise comparison matrices among risk groups and risk factors}

The next step was to conduct pairwise comparison matrices in Microsoft Excel to solve the FANP matrix. This was followed by the construction of a hierarchical network structure of pairwise comparison matrices to evaluate the respective importance of various risk groups and various risk factors within the same groups. The question was asked by the expert team as mentioned in Section 2 to compare each risk group and risk factor with attention to their impact on the objective of the project, including time, cost, quality, the probabilities of the occurrence of each risk and risk coupling in freeway projects.

The interdependence matrix of each risk factor had to be determined relatively to other risk factors based on the used fuzzy scales based on the Chang's fuzzy AHP method (Chang 1996). A triangular fuzzy number was inserted in the related Microsoft Excel sheet according to the result received from this linguistic scale. All average comparisons obtained from expert answers were solved using Microsoft Excel. The received average answers were keyed into the version (2.2.6) of Super Decision software to calculate the consistency of pairwise comparison matrices. The value of consistency ratio $(C R)$ was used for checking consistency according to the pairwise comparison. If the consistency value of $C R$ was less than 0.1 , it would be evident that such a pairwise comparison matrix contained satisfactory consistency. In the case sample, pairwise comparisons were seen to be consistent. Otherwise, evaluation should be considered by an expert team. Tables 6 and 7 show a pairwise comparison matrix of a change in market demand between the groups of market risks and a pairwise comparison matrix between the groups of risks, respectively.

The data keyed into the Microsoft Excel sheet had to include related importance in order to take into account relative weights (Kahraman et al. 2006). Data that were keyed into the matrixes were extended to solve FANP matrices, which provided normalized weight vectors $(W)$. 
Table 6. Pairwise comparison matrix between the groups of risks

\begin{tabular}{l|l|l|l|l|l|l|l|l}
\hline & \multicolumn{1}{|c|}{$R_{1}$} & \multicolumn{1}{c|}{$R_{2}$} & \multicolumn{1}{c}{$R_{3}$} & \multicolumn{1}{c}{$R_{4}$} & \multicolumn{1}{c}{$R_{5}$} & \multicolumn{1}{c}{$R_{6}$} & \multicolumn{1}{c}{$R_{7}$} & \multicolumn{1}{c}{$W$} \\
\hline$R_{1}$ & $(1,1,1)$ & $(1,3 / 2,2)$ & $(3 / 2,2,5 / 2)$ & $(2,5 / 2,3)$ & $(5 / 2,3,7 / 2)$ & $(1,3 / 2,2)$ & $(2 / 3,1,2)$ & 0.336 \\
$R_{2}$ & $(1 / 2,2 / 3,1)$ & $(1,1,1)$ & $(1,3 / 2,2)$ & $(3 / 2,2,5 / 2)$ & $(2,5 / 2,3)$ & $(5 / 2,3,7 / 2)$ & $(3 / 2,2,5 / 2)$ & 0.334 \\
$R_{3}$ & $(2 / 5,1 / 2,2 / 3)$ & $(1 / 2,2 / 3,1)$ & $(1,1,1)$ & $(1,3 / 2,2)$ & $(2,5 / 2,3)$ & $(3 / 2,2,5 / 2)$ & $(1,3 / 2,2)$ & 0.206 \\
$R_{4}$ & $(1 / 3,2 / 5,1 / 2)$ & $(2 / 5,1 / 2,2 / 3)$ & $(1 / 2,2 / 3,1)$ & $(1,1,1)$ & $(2 / 5,1 / 2,2 / 3)$ & $(3 / 2,2,5 / 2)$ & $(1,3 / 2,2)$ & 0.046 \\
$R_{5}$ & $(2 / 7,1 / 3,2 / 5)$ & $(1 / 3,2 / 5,1 / 2)$ & $(1 / 3,2 / 5,1 / 2)$ & $(3 / 2,2,5 / 2)$ & $(1,1,1)$ & $(1,3 / 2,2)$ & $(1 / 2,1,3 / 2)$ & 0.049 \\
$R_{6}$ & $(1 / 2,2 / 3,1)$ & $(2 / 7,1 / 3,2 / 5)$ & $(2 / 5,1 / 2,2 / 3)$ & $(2 / 5,1 / 2,2 / 3)$ & $(1 / 2,2 / 3,1)$ & $(1,1,1)$ & $(2,5 / 2,3)$ & 0.017 \\
$R_{7}$ & $(1 / 2,1,3 / 2)$ & $(2 / 5,1 / 2,2 / 3)$ & $(1 / 2,2 / 3,1)$ & $(1 / 2,2 / 3,1)$ & $(2 / 3,1,2)$ & $(1 / 3,2 / 5,1 / 2)$ & $(1,1,1)$ & 0.012 \\
\hline
\end{tabular}

Table 7. Pairwise comparison matrix of a change in market demand $\left(r_{41}\right)$

\begin{tabular}{l|l|l|l|l}
\hline & \multicolumn{1}{|c|}{$r_{42}$} & \multicolumn{1}{c|}{$r_{43}$} & \multicolumn{1}{c}{$r_{44}$} & $W$ \\
\hline$r_{42}$ & $(1,1,1)$ & $(3 / 2,2,5 / 2)$ & $(1 / 2,1,3 / 2)$ & 0.41 \\
$r_{43}$ & $(2 / 5,1 / 2,2 / 3)$ & $(1,1,1)$ & $(3 / 2,2,5 / 2)$ & 0.35 \\
$r_{44}$ & $(2 / 3,1,2)$ & $(2 / 5,1 / 2,2 / 3)$ & $(1,1,1)$ & 0.24 \\
\hline
\end{tabular}

Vector $W$ was a non-fuzzy number, and the normalized $W$ of risk factors was calculated using the Chang's method (1996). The values of fuzzy synthetic extents with respect to the criteria were calculated as follows:

$$
\begin{aligned}
S_{r 42}= & (3,4,5) \otimes(0.0779,0.1,0.125)= \\
& (0.233,0.4,0.627) ; \\
S_{r 43}= & (2.9,3.5,4.167) \otimes(0.0779,0.1,0.125)= \\
& (0.225,0.35,0.523) ; \\
S_{r 44}= & (2.067,2.5,3.67) \otimes(0.0779,0.1,0.125)= \\
& (0.161,0.25,0.460) .
\end{aligned}
$$

The degrees of possibility were calculated as:

$$
\begin{aligned}
& V\left(S_{r 42} \geq S_{r 43}\right)=1, V\left(S_{r 42} \geq S_{r 44}\right)=1 ; \\
& V\left(S_{r 43} \geq S_{r 42}\right)=0.853, V\left(S_{r 43} \geq S_{r 44}\right)=1 ; \\
& V\left(S_{r 44} \geq S_{r 42}\right)=0.601, V\left(S_{r 44} \geq S_{r 43}\right)=0.7 .
\end{aligned}
$$

For each pairwise comparison, the minimum of the degrees of possibility was determined as:

$$
\begin{aligned}
& V\left(S_{r 42} \geq S_{r 43}, S_{r 44}\right)=\min \{1,1\}=1 ; \\
& V\left(S_{r 43} \geq S_{r 42}, S_{r 44}\right)=\min \{0.852,1\}=0.852 ; \\
& V\left(S_{r 44} \geq S_{D 42}, S_{r 43}\right)=\min \{0.601,0.7\}=0.601 .
\end{aligned}
$$

These values yielded the following weight vector:

$$
W^{\prime}=(1,0.852,0.601) .
$$

Via normalization, the local weights of the criteria were determined as follows:

$$
W=(0.41,0.35,0.24)
$$

The values of sample $W$ were inserted into Super Decisions software manually and are shown in Figure 4.

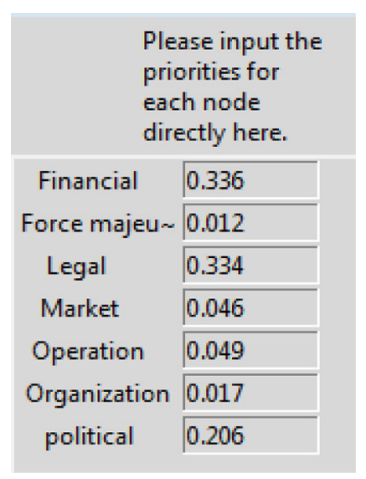

Fig. 4. Sample snapshot of Super Decisions software considering risk group version 2.2.6

\subsection{Determining un-weighted, weighted and limited super-matrices}

The next stage was to create un-weighted, weighted and limited super-matrices. The un-weighted super-matrix included local priorities insulated from pairwise comparisons. Influence priority was assigned as zero while an element is considered to have no efficacy on another element (Saaty 2005).

As regards this method, the component was weighted with its corresponding cluster matrix weight. Then, the weighted super-matrix was converted to a limited matrix by raising the weighted super-matrix to powers by multiplying it by itself (Saaty 2005). The results of priorities for risk factors were extracted and obtained from the limited matrix. The above computing process was accomplished using ANP version 2.2.4 of Super Decision software. The un-weighted and weighted super-matrices falling into the group of financial risks are shown in Tables 8 and 9 , respectively.

\subsection{Final ranking of risk groups and risk factors}

The outcome of limited matrix weights for the final ranking has been used. The weight of each risk group was obtained from a cluster of matrix priorities. The final ranking of each risk factor was received from the results of the limited matrix taking into account priorities for Super Decision software. 
Table 8. Un-weighted super matrix of group $R_{1}$

\begin{tabular}{c|l|l|l|l|l|l}
\hline & $r_{11}$ & $r_{12}$ & $r_{13}$ & $r_{14}$ & $r_{15}$ & $r_{16}$ \\
\hline$r_{11}$ & 0.00000 & 0.087035 & 0.087035 & 0.083460 & 0.082429 & 0.076015 \\
$r_{12}$ & 0.216872 & 0.00000 & 0.347846 & 0.218333 & 0.219131 & 0.229454 \\
$r_{13}$ & 0.392492 & 0.347846 & 0.00000 & 0.411333 & 0.399106 & 0.414263 \\
$r_{14}$ & 0.181269 & 0.251926 & 0.251926 & 0.00000 & 0.169835 & 0.161482 \\
$r_{15}$ & 0.070709 & 0.120803 & 0.120803 & 0.122587 & 0.00000 & 0.118787 \\
$r_{16}$ & 0.138658 & 0.192390 & 0.192390 & 0.164286 & 0.129499 & 0.00000 \\
\hline
\end{tabular}

Table 9. Weighted super matrix of group $R_{1}$

\begin{tabular}{l|l|l|l|l|l|l}
\hline & $r_{11}$ & \multicolumn{1}{|c|}{$r_{12}$} & $r_{13}$ & \multicolumn{1}{c|}{$r_{14}$} & $r_{15}$ & $r_{16}$ \\
\hline$r_{11}$ & 0.00000 & 0.087035 & 0.087035 & 0.083460 & 0.082429 & 0.076015 \\
$r_{12}$ & 0.048480 & 0.00000 & 0.347846 & 0.218333 & 0.219131 & 0.229454 \\
$r_{13}$ & 0.087739 & 0.347846 & 0.00000 & 0.411333 & 0.399106 & 0.414263 \\
$r_{14}$ & 0.040522 & 0.251926 & 0.251926 & 0.00000 & 0.169835 & 0.161482 \\
$r_{15}$ & 0.015806 & 0.120803 & 0.120803 & 0.122587 & 0.00000 & 0.118787 \\
$r_{16}$ & 0.030996 & 0.192390 & 0.192390 & 0.164286 & 0.129499 & 0.00000 \\
\hline
\end{tabular}

\section{Discussion and results}

Effective risk management requires a serious examination of the risk management process of identifying, assessing and managing risks. This study proposes an improved risk assessment method for freeway PPP projects introducing a freeway project as a case study in Iran. We have reviewed literature published over the past few years in relation to PPP project risks and rechecked risk items with freeway project experts. The fuzzy analytic network process (FANP) approach has been employed to assess the associated risks.

The use of fuzzy concepts for collecting pairwise comparison data on the probability of occurrence and risk impact on project performance created by engineers and experts confirmed that the proposed procedure simplified the data collection process. This method could raise the inclination of the participating experts and engineers to give their perceptions of risk information for objective projects. The use of pairwise comparisons for assessing risks with respect to criteria and sub-criteria was meant to increase the accuracy of risk assessment the findings of which were applied in the risk response step.

The final ranking of each risk factor using FANP weights is presented in Table 10 where limited capital $\left(r_{16}\right)$ is the top imprtant risk with a weight of 0.1539 . The priorotizion of risks showed that improper design $\left(r_{21}\right)$ was the second important risk factor with a weight of 0.1072 . This risk increases legal claims due to additional design work and extra delays. Among other risk factors, change in the value of granted lands due to development $\left(r_{11}\right)$ and the termination of concession by the government $\left(r_{31}\right)$ can be mentioned; these were among the most important risk factors calculated at 0.0885 and 0.0866 respectively. On the other hand, organization risks $\left(r_{62}\right)$ and
Table 10. Weight of risk factors

\begin{tabular}{c|l|l|l}
\hline $\begin{array}{c}\text { Risk } \\
\text { factors }\end{array}$ & Weights & $\begin{array}{c}\text { Risk } \\
\text { factors }\end{array}$ & Weights \\
\hline$r_{16}$ & 0.1539 & $r_{27}$ & 0.026 \\
$r_{21}$ & 0.1072 & $r_{61}$ & 0.0245 \\
$r_{11}$ & 0.0885 & $r_{41}$ & 0.0212 \\
$r_{31}$ & 0.0866 & $r_{32}$ & 0.02 \\
$r_{13}$ & 0.065 & $r_{26}$ & 0.0183 \\
$r_{12}$ & 0.0638 & $r_{25}$ & 0.014 \\
$r_{22}$ & 0.0554 & $r_{34}$ & 0.0109 \\
$r_{71}$ & 0.0534 & $r_{33}$ & 0.0068 \\
$r_{14}$ & 0.0457 & $r_{52}$ & 0.0016 \\
$r_{23}$ & 0.0381 & $r_{43}$ & 0.0012 \\
$r_{15}$ & 0.0322 & $r_{53}$ & 0.001 \\
$r_{51}$ & 0.0307 & $r_{42}$ & 0.0006 \\
$r_{24}$ & 0.0305 & $r_{44}$ & 0.0004 \\
& & $r_{62}$ & 0.0001 \\
\hline
\end{tabular}

market competition $\left(r_{44}\right)$ were the least important making 0.0004 and 0.0001 respectively.

The evaluation of the final result regarding risk groups is shown in Table 11. Financial and legal risk groups were the most important ones compared to other risks with the weights of 0.4491 and 0.2895 respectively. Inflation, sanctions and rising prices of land ownership were determined to be the three main reasons behind financial risk. Legal risk has caused an insufficient standard model for PPP contracts, remaining general and special contract conditions susceptible to challenge and poor execution management. Additionally, risk for ownership assets has threatened private assets, especially with re- 
Table 11. Weight of each risk group

\begin{tabular}{l|c}
\hline Group of risk & Weight of each group \\
\hline Financial & 0.4491 \\
Legal & 0.2895 \\
Political & 0.1243 \\
Force majeure & 0.0534 \\
Operation and Maintenance & 0.0335 \\
Organization and coordination & 0.0258 \\
Market & 0.0234 \\
\hline
\end{tabular}

gards to peripheral facilities, because their worth could be noticeable but there are no estimates of them.

In October 2010, the Government represented by the Ministry of Transportation and a Road Construction Company signed the Isfahan-Shiraz freeway concession agreement. The contract term was 18 years, which included 4 years for construction and 14 years for operation. The current progress of the Isfahan-Shiraz freeway amounts to $20 \%$. $50 \%$ of financial resources required for project construction were to be provided by the Government and $12.5 \%$ and $25 \%$ of the total investment were to be provided by Sepah Bank and Khatamul Anbiya company, respectively (Esfahan-Shiraz Co. 2015). In order to compare the presented findings of research with the actual risk management situation, we interviewed the selected risk management team as described in Section 2 from those involved in the Isfahan-Shiraz freeway project. The respondents were asked to confirm ranking top risks from research results comparing with the actual top risks in the presented case study. Although the project was launched in 2010, the implementation of that started in 2012 with a 2 year delay the most important reasons for which were lack of funding and land acquisition (Esfahan-Shiraz Co. 2015). Cost and time for land acquisition exceeded original plans. The original contract did not address environmental issues. Due to the fact that the major part of the project land amounting to 70 million $\mathrm{m}^{2}$ was located in Iran's Zagrous forests, demand for environmental protection became a problem of project financing and delay. Project managers believed that financial risks, especially limited capital, were the main concerns in this case study. Financing risk has an implicit impact on delay or incompletion risk, including inflation risk, change in the value of granted lands due to development, change in the value of granted lands due to inflation and financial problems of environmental protection. The rates of inflation are indexed; therefore, projected revenues and, consequently, achievements in the designated rate of return would be adversely affected in case the inflation rate is lower than what has been assumed in the financial model. Economic conditions made it difficult to accurately predict inflation rates, potentially affecting both project costs and the value of granted lands (Heravi, Hajihosseini 2011). Moreover, the value of granted lands would increase should they become more desirable for development. As for this case study, inflation risk increased the total cost by $15 \%$ (Esfahan-Shiraz Co. 2015). Ghorbani et al. (2014) declared financial risk as the most important risk for the construction of the highway PPP project in Iran. Heravi and Hajihosseini (2011) mentioned that financial risk and land acquisition were the most important risks in the implementation of Tehran-Chalus highway project. In addition, the risk management team and project managers believed that improper design and force majeure risks that included severe weather and hazard risks had a negative impact on project implementation and the objectives of projects on Isfahan-Shiraz freeway. These risk events are responsible for a poor quality of work, delays and associated losses due to bad natural conditions for the project site, for example, climate, a specific geographical environment, poor site conditions, etc. According to Ghorbani et al. (2014), Mousavi et al. (2011) and Heravi and Hajihosseini (2011) force majeure and improper design were the most important risks in Iranian highway PPP projects. Ultimately, Isfahan-Shiraz freeway is expected to be operational in 2017 with a 3 -year delay. Finally, the results show there is only one difference between ranked top risks that were obtained in this research and real significant risk in the case study that includes 'termination of concession by the Government' risk. Therefore, the experts have mentioned that risk rating derived from the purpose model is acceptable from their point of view. The stakeholders of freeway PPP projects can choose appropriate strategies for handling risk response using this information.

\section{Validity of the obtained results and proposed model}

In order to test the validity of the obtained results, the direct results of prioritized risks faced by the experts were compared by four other methods including Fuzzy, ANP, FAHP and FANP (Zegordi et al. 2012). To achieve this, eight experts having over 10 years of experience in freeway PPP projects were selected (see Table 1). The final rankings of risks using these methods are presented in Figure 5. As the figure shows, $r_{16}$ and $r_{21}$ are the most important risks in all methods. On the other hand, in all methods, $r_{44}$ and $r_{62}$ are the least important risks. The figure clearly indicates there are no significant differences between the obtained rankings of the top 4 risks $\left(r_{16}, r_{21}\right.$, $r_{11}$ and $r_{31}$ ) using the proposed method and expert opinion. There are only three differences in ranking for $r_{13}$, $r_{22}$ and $r_{14}$ between the proposed model and expert opinion. The received results also show that a deviation from the FANP method and expert opinions is $7.40 \%$, which is less than $10 \%$. In addition, Figure 5 shows there are $14.814 \%, 25.925 \%$ and $29.629 \%$ deviations from ranking risk between ANP, FAHP, Fuzzy and opinion experts respectively. The experts have approved deviations from their judgments as they have mentioned that risk rating derived from the FANP is acceptable from their point of view. Therefore, the validity of the results is seen. 


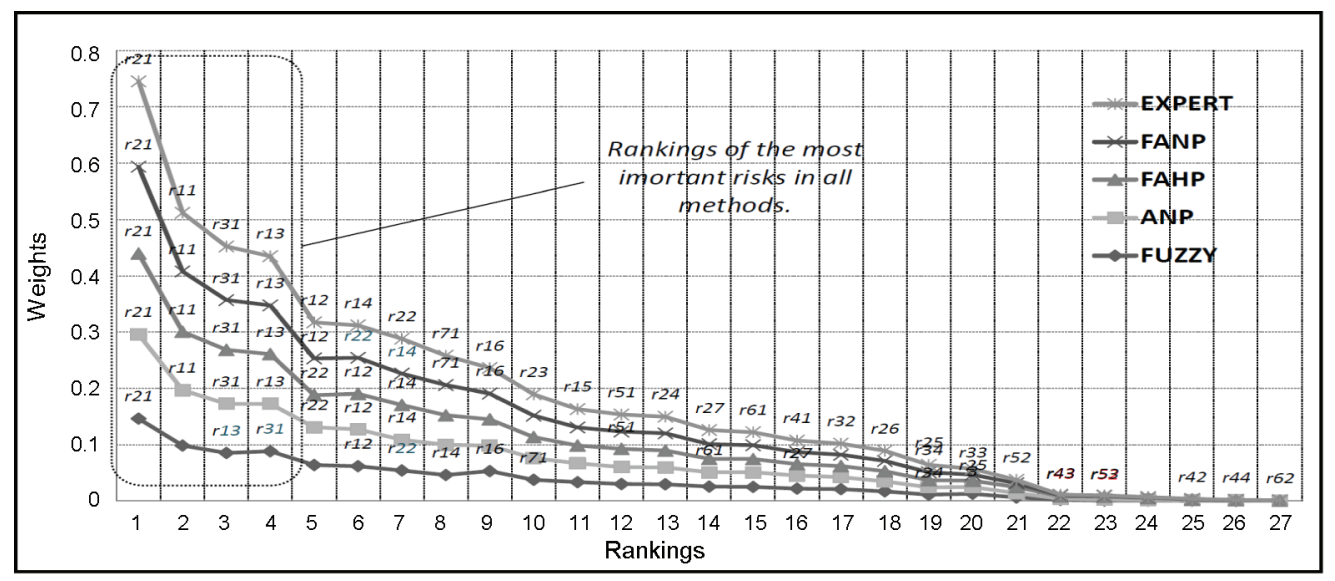

Fig. 5. A comparison of the results of the proposed model and other four methods

Table 12. Results of the validation exercise of the risk prioritization model

\begin{tabular}{l|c|c|c|c|c|c|c|c|c}
\hline \multicolumn{1}{c|}{ Validation criteria } & \multicolumn{5}{c|}{ Scores rated by experts } & \multicolumn{2}{c}{ Average scores } \\
\hline $\begin{array}{l}\text { 1. Degree of the comprehensiveness of the risks } \\
\text { included in the model }\end{array}$ & 4 & 5 & 5 & 4 & 5 & 5 & 5 & 4 & 4.625 \\
2. Degree of the objectivity of the model & 5 & 5 & 5 & 4 & 5 & 4 & 5 & 5 & 4.75 \\
3. Degree of the clarity of the model & 4 & 4 & 5 & 5 & 4 & 4 & 5 & 4 & 4.375 \\
4. Overall reliability of the model & 5 & 5 & 5 & 4 & 4 & 4 & 5 & 5 & 4.625 \\
5. Degree of the practicality of the model & 3 & 3 & 4 & 5 & 5 & 4 & 4 & 4 & 4 \\
\hline
\end{tabular}

A total of eight interviews were launched for validating the model. Eight experts were invited to evaluate the (1) degree of the comprehensiveness of risks included in the model; (2) the degree of the objectivity of the model; (3) the degree of the clarity of the model; (4) the overall reliability of the model; and (5) the degree of the practicality of the model. The model was offered to the experts to make certain they realized the background of this research, the procedure for how this particular model was created and the possible application of the model throughout face-to-face interviews. A question-and-answer session was organized to provide them a chance to raise questions if they had any about the contents of the presentation. Finally, the experts were asked to fill out a validation form with five multiple-choice questions using a five-point Likert scale where 1 denoted 'poor' and 5 denoted 'excellent'. The average scores of all five criteria are well above 3.50 , so, the result confirmed that the model is considered to be comprehensive, clear, objective, practical and reliable by the experts in the validation exercise (Yeung et al. 2007). The previously mentioned selection criteria are consistent with similar validations of models for research on construction management. For instance, Yeung et al. (2009) produced a computerized model for calculating joining-up performance associated with construction projects in Hong Kong. The results of validation experts were tabulated in Table 12.

The average scores of all five criteria are well above 3.50 , so the received result confirmed the model was con- sidered to be comprehensive, clear, objective, practical and reliable by the experts in the validation exercise.

\section{Conclusions}

The main objective of this study was to identify significant risks in freeway projects and to develop a risk prioritization approach to freeway PPP projects. In reality, stakeholders have a limited knowledge of managing all project risks. Therefore, they need to wisely prioritize important risks. This paper has adopted a fuzzy ANP approach to developing a risk prioritization model for freeway PPP projects and implemented the model on a case study in Iran. The FANP, as a method of compounding quantitative and qualitative methods, has an advantage of applying the influence of complex problems, the instances of which contain relationships and feedback. The obtained results have showed that the top three risk groups of freeway PPP projects in Iran were financial $\left(R_{1}\right)$, legal $\left(R_{2}\right)$ and political risks $\left(R_{3}\right)$. It can be concluded that limited capital $\left(r_{16}\right)$ is the most important risk in such projects. Among other risk factors, improper design $\left(r_{21}\right)$, change in the value of granted lands $\left(r_{11}\right)$ and the termination of concession $\left(r_{31}\right)$ are critically important. By using the FANP, a risk prioritization model for PPP projects, the Government and private sectors will be able to identify the source of risk prior to the implementation of the project, and discretionary action could be obtained as soon as possible. The proposed model can prepare decisions with reference to risk prioritization and project risk 
management in PPP projects. In future researches, other multiple-criteria methods can be used for evaluating the risks of PPP freeway projects along with other projects in different sectors. To select response actions, it is also advisable to focus on the integrated optimization model.

\section{Acknowledgements}

The work described in this paper has been fully supported by a joint grant from research grants MOSTI (Malaysia, UTM\& Vote No. (4S084)).

\section{References}

Alireza, V.; Mohammadreza, Y.; Zin, R. M.; Yahaya, N.; Noor, N. M. 2013. An enhanced multi-objective optimization approach for risk allocation in public-private partnership projects: a case study of Malaysia, The Canadian Journal of Civil Engineering 41(2): 164-177. http://dx.doi.org/10.1139/cjce-2013-0342

APM. 2004. Project risk analysis and management guide. High Wycombe: APM Publishing Ltd. $186 \mathrm{p}$.

Ayağ, Z.; Özdemir, R. G. 2007. An intelligent approach to ERP software selection through fuzzy ANP, International Journal of Production Research 45(10): 2169-2194. http://dx.doi.org/10.1080/00207540600724849

Azizi, M.; Modarres, M. 2007. A strategic model for location selection of wood industry: an application of ANP, Journal of Applied Sciences 7(3): 326-333. http://dx.doi.org/10.3923/jas.2007.326.333

Baloi, D.; Price, A. D. 2003. Modelling global risk factors affecting construction cost performance, International Journal of Project Management 21(4): 261-269. http://dx.doi.org/10.1016/S0263-7863(02)00017-0

Bayazit, O. 2006. Use of analytic network process in vendor selection decisions, Benchmarking: An International Journal 13(5): 566-579.

http://dx.doi.org/10.1108/14635770610690410

Berner, F.; Hermes, M.; Weigl, A. 2014. Risk assessment of PPP contracts, Bauingenieur 89: 416-420.

Bu-Qammaz, A. S.; Dikmen, I.; Birgonul, M. T. 2009. Risk assessment of international construction projects using the analytic network process, Canadian Journal of Civil Engineering 36(7): 1170-1181. http://dx.doi.org/10.1139/L09-061

Carr, V.; Tah, J. 2001. A fuzzy approach to construction project risk assessment and analysis: construction project risk management system, Advances in Engineering Software 32(10): 847-857. http://dx.doi.org/10.1016/S0965-9978(01)00036-9

Chan, F. T.; Kumar, N.; Tiwari, M.; Lau, H.; Choy, K. 2008. Global supplier selection: a fuzzy-AHP approach, International Journal of Production Research 46(14): 3825-3857. http://dx.doi.org/10.1080/00207540600787200

Chang, D.-Y. 1996. Applications of the extent analysis method on fuzzy AHP, European Journal of Operational Research 95(3): 649-655. http://dx.doi.org/10.1016/0377-2217(95)00300-2

Cheng, J.-H.; Tang, C.-H. 2009. An application of fuzzy Delphi and fuzzy AHP for multi-criteria evaluation on bicycle industry supply chains, WSEAS Transactions on Systems and Control 4(1): 21-34.

Chou, J.-S.; Tsai, C.-F.; Lu, Y.-H. 2013. Project dispute prediction by hybrid machine learning techniques, Journal of Civil Engineering and Management 19(4): 505-517. http://dx.doi.org/10.3846/13923730.2013.768544
Dağdeviren, M.; Yüksel, İ. 2010. A fuzzy analytic network process (ANP) model for measurement of the sectoral competition level (SCL), Expert Systems with Applications 37(2): 1005-1014. http://dx.doi.org/10.1016/j.eswa.2009.05.074

Delmon, J. 2000. BOO and BOT projects: a commercial and contractual guide. Sweet \& Maxwell, USA. 272 p.

Deng, X.; Low, S. P.; Li, Q.; Zhao, X. 2014. Developing competitive advantages in political risk management for international construction enterprises, Journal of Construction Engineering and Management 140(9), 04014040. http://dx.doi.org/10.1061/(ASCE)CO.1943-7862.0000836

Ebrahimnejad, S.; Mousavi, S. M.; Seyrafianpour, H. 2010. Risk identification and assessment for build-operate-transfer projects: a fuzzy multi attribute decision making model, Expert Systems with Applications 37(1): 575-586. http://dx.doi.org/10.1016/j.eswa.2009.05.037

Ertuğrul, İ.; Karakaşoğlu, N. 2009. Performance evaluation of Turkish cement firms with fuzzy analytic hierarchy process and TOPSIS methods, Expert Systems with Applications 36(1): 702-715. http://dx.doi.org/10.1016/j.eswa.2007.10.014

Eshtehardian, E.; Ghodousi, P.; Bejanpour, A. 2013. Using ANP and AHP for the supplier selection in the construction and civil engineering companies: case study of Iranian company, KSCE Journal of Civil Engineering 17(2): 262-270. http://dx.doi.org/10.1007/s12205-013-1141-z

Esfahan-Shiraz Co. 2015. Implementation sections [online], [cited 10 Apr 2015]. Available from Internet: http://www.eshfc.ir/main fa.asp

Ghorbani, A.; Ravanshadnia, $\bar{M}$.; Nobakht, M. B. 2014. A survey of risks in public private partnership highway projects in Iran, in ICCREM 2014@sSmart Construction and Management in the Context of New Technology, 2014, ASCE, 482-492.

Guneri, A. F.; Cengiz, M.; Seker, S. 2009. A fuzzy ANP approach to shipyard location selection, Expert Systems with Applications 36(4): 7992-7999.

http://dx.doi.org/10.1016/j.eswa.2008.10.059

Heravi, G.; Hajihosseini, Z. 2011. Risk allocation in publicprivate partnership infrastructure projects in developing countries: case study of the Tehran-Chalus Toll Road, Journal of Infrastructure Systems 18(3): 210-217. http://dx.doi.org/10.1061/(ASCE)IS.1943-555X.0000090

Kahraman, C.; Ertay, T.; Büyüközkan, G. 2006. A fuzzy optimization model for QFD planning process using analytic network approach, European Journal of Operational Research 171(2): 390-411. http://dx.doi.org/10.1016/j.ejor.2004.09.016

Karim, A.; Alkaf, N. 2011. Risk allocation in public private partnership (PPP) project: a review on risk factors, International Journal of Sustainable Construction Engineering and Technology 2(2): 8-16.

Kaur, P.; Mahanti, N. 2008. A fuzzy ANP-based approach for selecting ERP vendors, International Journal of Soft Computing 3(1): 24-32.

Ke, Y.; Wang, S. Q.; Chan, A. P. C. 2012. Risk management practice in China's public-private partnership projects, Journal of Civil Engineering and Management 18(5): 675-684. http://dx.doi.org/10.3846/13923730.2012.723380

Li, J.; Zou, P. X. 2011. Fuzzy AHP-based risk assessment methodology for PPP projects, Journal of Construction Engineering and Management 137(12): 1205-1209. http://dx.doi.org/10.1061/(ASCE)CO.1943-7862.0000362

Mikhailov, L.; Singh Madan, G. 2003. Fuzzy analytic network process and its application to the development of decision support systems, IEEE Transactions on Systems, Man, and 
Cybernetics, Part C: Applications and Reviews 33(1): 3341. http://dx.doi.org/10.1109/TSMCC.2003.809354

Mousavi, S. M.; Tavakkoli-Moghaddam, R.; Azaron, A.; Mojtahedi, S.; Hashemi, H. 2011. Risk assessment for highway projects using jackknife technique, Expert Systems with Applications 38(5): 5514-5524. http://dx.doi.org/10.1016/j.eswa.2010.10.085

Nasirzadeh, F.; Afshar, A.; Khanzadi, M. 2008. System dynamics approach for construction risk analysis, International Journal of Civil Engineering 6(2): 120-131.

$\mathrm{Ng}$, A.; Loosemore, M. 2007. Risk allocation in the private provision of public infrastructure, International Journal of Project Management 25(1): 66-76. http://dx.doi.org/10.1016/j.ijproman.2006.06.005

Peckiene, A.; Komarovska, A.; Ustinovicius, L. 2013. Overview of risk allocation between construction parties, Procedia Engineering 57: 889-894. http://dx.doi.org/10.1016/j.proeng.2013.04.113

Poh, Y.; Tah, J. 2006. Integrated duration-cost influence network for modelling risk impacts on construction tasks, Construction Management and Economics 24(8): 861868. http://dx.doi.org/10.1080/01446190600658891

Rabbani, A.; Zamani, M.; Yazdani-Chamzini, A.; Zavadskas, E. K. 2014. Proposing a new integrated model based on sustainability balanced scorecard (SBSC) and MCDM approaches by using linguistic variables for the performance evaluation of oil producing companies, Expert Systems with Applications 41: 7316-7327.

http://dx.doi.org/10.1016/j.eswa.2014.05.023

Rajan, T. A.; Gopinath, G.; Behera, M. 2013. PPPs and project overruns: Evidence from road projects in India, Journal of Construction Engineering and Management 140(5), 04013070.

http://dx.doi.org/10.1061/(ASCE)CO.1943-7862.0000797

Razmi, J.; Rafiei, H.; Hashemi, M. 2009. Designing a decision support system to evaluate and select suppliers using fuzzy analytic network process, Computers \& Industrial Engineering 57(4): 1282-1290.

http://dx.doi.org/10.1016/j.cie.2009.06.008

Valipour, A.; Sarvari, H.; Yahaya, N.; Md Noor, N.; Rashid, A. S. A. 2013. Analytic network process (ANP) to risk assessment of gas refinery EPC projects in Iran, Journal of Applied Sciences Research 9(3): 1359-1365.

http://dx.doi.org/10.4028/www.scientific.net/AMM.567.654

Ribeiro, P.; Paiva, A.; Varajão, J.; Dominguez, C. 2013. Success evaluation factors in construction project management some evidence from medium and large Portuguese companies, KSCE Journal of Civil Engineering 17(4): 603-609. http://dx.doi.org/10.4028/10.1007/s12205-013-0019-4.

Saaty, T. L. 1996. Decision making with dependence and feedback: The analytic network process. Pittsburgh: RWS Publications. 370 p.

Saaty, T. L. 2005. Theory and applications of the analytic network process: decision making with benefits, opportunities, costs, and risks. Pittsburgh: RWS Publications. 352 p.

Saaty, T. L.; Vargas, L. G. 2006. Decision making with the analytic network process. New York: Springer Science. 363 p.

Shafieezadeh, M.; Hajfataliha, A. 2009. A conceptual framework for supply chain coordination in fuzzy environment, Journal of Theoretical and Applied Information Technology 8(2): 123-135.

Shafiee, M. 2015. A fuzzy analytic network process model to mitigate the risks associated with offshore wind farms, Expert Systems with Applications 42(4): 2143-2152. http://dx.doi.org/10.1016/j.eswa.2014.10.019

Shrestha, M. 2011. Risk framework for public private partnerships in highway construction. University of WisconsinMadison, USA. 29 p.
Tang, W.; Zhang, F.; Ye, Z.; Li, J. 2011. Research on risk evaluation in urban rail transit project, Procedia Engineering 15: 5094-5099.

http://dx.doi.org/10.1016/j.proeng.2011.08.945

Teller, J.; Kock, A.; Gemünden, H. G. 2014. Risk management in project portfolios is more than managing project risks: A contingency perspective on risk management, Project Management Journal 45(4): 67-80. http://dx.doi.org/10.1002/pmj.21431

Tserng, H. P.; Ho, S.-P.; Chou, J.-S.; Lin, C. 2014. Proactive measures of governmental debt guarantees to facilitate public-private partnerships project, Journal of Civil Engineering and Management 20(4): 548-560. http://dx.doi.org/10.3846/13923730.2013.801883

Turskis, Z.; Gajzler, M.; Dziadosz, A. 2012. Reliability, risk management, and contingency of construction processes and projects, Journal of Civil Engineering and Management 18(2): 290-298. http://dx.doi.org/10.3846/13923730.2012.672931

Vahidnia, M.; Alesheikh, A.; Alimohammadi, A.; Bassiri, A. 2008. Fuzzy analytical hierarchy process in GIS application, The International Archives of the Photogrammetry, Remote Sensing and Spatial Information Sciences 37(B2): 593-596.

Wu, C.-R.; Chang, C.-W.; Lin, H.-L. 2008. A fuzzy ANP-based approach to evaluate medical organizational performance, International Journal of Management Science 19(1): 53-74.

Xu, Y.; Chan, A. P.; Yeung, J. F. 2010. Developing a fuzzy risk allocation model for PPP projects in China, Journal of Construction Engineering and Management 136(8): 894903.

http://dx.doi.org/10.1061/(ASCE)CO.1943-7862.0000189

Xu, Y.; Lu, Y.; Chan, A. P. C.; Skibniewski, M. J.; Yeung, J. F. Y. 2012. A computerized risk evaluation model for publicprivate partnership (PPP) projects and its application, International Journal of Strategic Property Management 16(3): 277-297. http://dx.doi.org/10.3846/1648715X.2014.971088

Xu, Y.; Yeung, J. F. Y.; Jiang, S. 2014. Determining appropriate government guarantees for concession contract: lessons learned from 10 PPP projects in China, International Journal of Strategic Property Management 18(4): 356367. http://dx.doi.org/10.3846/1648715X.2014.971088.

Yu, J.-H.; Lee, S.-K. 2012. A conflict-risk assessment model for urban regeneration projects using Fuzzy-FMEA, KSCE Journal of Civil Engineering 16(7): 1093--1103. http://dx.doi.org/10.1007/s12205-012-1196-2

Yeung, J. F.; Chan, A. P.; Chan, D. W. 2009. A computerized model for measuring and benchmarking the partnering performance of construction projects, Automation in Construction 18(8): 1099-1113.

http://dx.doi.org/10.1016/j.autcon.2009.07.003

Yeung, J. F.; Chan, A. P.; Chan, D. W.; Li, L. K. 2007. Development of a partnering performance index (PPI) for construction projects in Hong Kong: a Delphi study, Construction Management and Economics 25(12): 1219-1237. http://dx.doi.org/10.1080/01446190701598673

Yun, S.; Jung, W.; Han, S. H.; Park, H. 2015. Critical organizational success factors for public private partnership projects - a comparison of solicited and unsolicited proposals, Journal of Civil Engineering and Management 21(2): 131-143. http://dx.doi.org/10.3846/13923730.2013.802715

Zadeh, L. A. 1976. A fuzzy-algorithmic approach to the definition of complex or imprecise concepts, International Journal of Man-Machine Studies 8(3): 249-291. http://dx.doi.org/10.1016/S0020-7373(76)80001-6

Zegordi, S.; Nik, E.; Nazari, A. 2012. Power plant project risk assessment using a fuzzy-ANP and fuzzy-TOPSIS 
method, International Journal of Engineering-Transactions B: Applications 25(2): 107-120.

Zhang, X. 2005. Critical success factors for public-private partnerships in infrastructure development, Journal of Construction Engineering and Management 131(1): 3-14. http://dx.doi.org/10.1061/(ASCE)0733-9364(2005)131:1(3)

Alireza VALIPOUR. He is currently a PhD student at the Faculty of Civil Engineering of Universiti Teknologi Malaysia (UTM). He obtained BSc in Civil Engineering and MSc in Construction Management from Islamic Azad University (IAU). His main research interests include the application of multiple criteria decision making theories in construction management, construction technology, project management and PPP risk management.

Nordin YAHAYA. Obtained his Bachelor's Degree in Civil Engineering (BEng) from Salford University, United Kingdom and Master's Degree in Engineering (Offshore Engineering) from the School of Industrial Science, Cranfield University, United Kingdom. He completed his $\mathrm{PhD}$ in the area of Offshore Engineering from Heriot-Watt University, United Kingdom. Currently, he is a Professor at the Faculty of Civil Engineering of UTM. He has also been appointed as the Senior Director of UTM International. His main research interests include the application of multiple criteria decision making theories in construction management, project management, PPP risk management and pipeline Soil-Corrosion Integrity Assessment.

Norhazilan MOHAMAD NOOR. Obtained his Bachelor's Degree in Civil Engineering (BEng) in 2000 and Master's Degree in Engineering (MEng. Structure) in 2002 from Universiti Teknologi Malaysia (UTM). He completed his PhD in the area of reliability assessment from Heriot-Watt University, Edinburgh, Scotland, in 2006. Currently, he is an Associate Professor at the Faculty of Civil Engineering of UTM. He has also been appointed as an Academic Coordinator for Postgraduates (research) in UTM. He is a former editor-in-chief of the Malaysian Journal of Civil Engineering. His main research interests include the application of multiple criteria decision making theories in construction management, project management, reliability assessment, PPP risk management and pipeline Soil-Corrosion Integrity Assessment.

Simona KILDIENE. Researcher at the Research Institute of Smart Building Technologies at Vilnius Gediminas Technical University. $\mathrm{PhD}$ in Construction Technology and Management from VGTU, Vilnius, Lithuania. Master of Science (construction engineering) from VGTU, 2010. Bachelor of Science (construction management) from VGTU, 2008. Research interests: construction economics, construction management, construction technology, multiple criteria analysis and decision making theories.

Hadi SARVARI. He is currently a PhD student at the Faculty of Civil Engineering of Universiti Teknologi Malaysia (UTM). He obtained BSc in Civil Engineering and MSc in Construction Management from Islamic Azad University (IAU). His main research interests include the application of multiple criteria decision making theories in construction management, construction technology, project management and PPP risk management.

Abbas MARDANI. He is a PhD researcher at the Department of Management, Faculty of Management and Human Resource Development at Universiti Teknologi Malaysia (UTM). He received his Bachelor's Degree in Industrial Management and Master's Degree in Industrial Management, field of Operation and Production Management in Iran. His current research interests focus on the areas of operation and production management, including quality management (QM), supply chain management (SCM), knowledge management (KM), multiple criteria decision making (MCDM), fuzzy multiple criteria decision making (FMCDM), national culture, saving and energy in hotel and tourism and hospitality industry. 